\title{
Review of National Legislations Applicable to Seabed Mineral Resources Exploitation
}

\author{
Saul Roux and Catherine Horsfield
}

\section{$\mathbf{1}$ \\ Introduction}

In parallel to growing interest for seabed exploration and mining in the high seas, there has been increased interest for seabed mining activities within the national jurisdictions of coastal states. Seabed mining in the high seas and within national jurisdictions is not unconnected. Seabed mining in the high seas provides a good indication of the nature, status quo and future of seabed mining in national jurisdictions and vice versa. Notably, the direction of seabed mining in the high seas will influence the policy directions of nation states. $^{1}$

This chapter seeks to provide a broad overview of seabed mining within the national jurisdictions of sovereign coastal states. Section 2 provides a brief outline of international legal and governance instruments that are intended to provide a framework for national policy and decision-making on seabed mining.

Section 3 seeks to provide a comparative analysis of legal and policy approaches adopted by various countries in relation to seabed exploration and exploitation. This aims to offer insights into legal principles and mechanisms that have been used in response to seabed mining. This comparative analysis focuses on seabed mining, in respect of both exploration and exploitation, within the exclusive economic zones of five coastal states namely: New Zealand, Australia, Namibia, Mexico and Papua New Guinea. These cases are assessed primarily due to the fact that seabed mining proposals have been concentrated in these coastal states. Furthermore, they represent a diversity of policy approaches and regulatory regimes. These approaches have been diverse, due

1 Lawson, T (2015). Global Opposition Is Mounting Against the Latest Environmental Abuse Deep Sea Mining. Truthout <http://www.truth-out.org/news/item/34206-global-opposition -is-mounting-against-the-latest-environmental-abuse-deep-sea-mining? 
to different legal and governance regimes operating in these countries, ranging from permanent bans, moratoria, strategic environmental assessments, assessments by environmental agencies and preparation for exploitation.

Section 4 provides a more in-depth case study of South Africa, focusing on marine phosphate prospecting. The South African case provides strong insights into the potential risks of seabed mining applications in jurisdictions with limited regulatory and governance capacity. Issues such as socio-economic and environmental risks related to marine phosphate extraction and legal and governance challenges for South Africa are discussed in this section.

Section 5 provides a brief synthesis of approaches adopted by other countries and the legal and governance principles that underpinned these approaches. Overall, this seeks to provide a structure for decision-making on seabed mining in the national jurisdictions of coastal States.

\section{Seabed Mining in the High-Seas or National Jurisdictions}

It is important to differentiate between seabed mining within the exclusive economic zones of coastal States and seabed mining in the high seas or 'the Area' that lies beyond national jurisdictions. In the case of the high seas, seabed mining is governed by the United Nations Convention on the Law of the Sea (UNCLOS) and associated Mining Codes, and regulated by the International Seabed Authority. ${ }^{2}$ Seabed mining applications that fall within a country's exclusive economic zone (within national jurisdiction) are regulated by that country's domestic law. The international deep seabed area (the Area), regulated by the International Seabed Authority (ISA) comprises about 26o-million square kilometres. A total of 85 -million square kilometres of ocean falls within exclusive economic zones. ${ }^{3}$

National jurisdictions usually extend to 200 nautical miles $(370 \mathrm{~km})$ seaward from baselines running along the shore. However, countries may submit Continental Shelf Extension claims (See Chapter Brekke). The International Seabed Authority has no role in determining these claims. This is decided by the Commission on the Limits of the Continental Shelf, also established by UNCLOS. Maritime boundaries between states are generally decided by bilateral negotiation, sometimes with the aid of independent judicial bodies.

2 See Chapter 7 of this book, J. Dingwall, 'Commercial Mining Activities in the Deep Seabed Beyond National Jurisdiction: The International Legal Framework.'

3 www.isa.org.jm. 


\subsection{The United Nations Convention on the Law of Seas}

The United Nations Convention on the Law of the Sea (UNCLOS) confers coastal states with a broad range of sovereign rights and duties in relation to their exclusive economic zones. Such rights and duties relate to utilisation of living resources, fisheries management, species management, enforcement and compliance, exploitation of non-living resource, marine scientific research, the protection and preservation of the marine environment and any other activities related to economic exploitation and exploration, such as the production of energy from the water, currents and winds. ${ }^{4}$ This includes the seabed, subsoil and water column.

Articles $76-85^{5}$ outline the rights and duties of coastal States over the continental shelf. These rights relate primarily for the purpose of exploring and exploiting natural resources. These natural resources consist of mineral and other non-living resources of the seabed and subsoil together with living organisms belonging to sedentary species (immobile). In brief, the powers vested in coastal states over their continental shelves only relate to exploitation of specific resources.

In terms of Article 192 of UNCLOS, signatory States have a general obligation to protect and preserve the marine environment within and outside their jurisdiction. Article 194(1) directs signatory States to take all measures necessary 'to prevent, reduce and control pollution of the marine environment from any source, using for this purpose the best practicable means at their disposal'. States are also required to take all measures necessary to ensure activities within their jurisdiction do not cause damage to other States and their environment. This duty is important in the case of seabed mining, where the impacts may extend to the exclusive economic zones (EEZ) of neighbouring states. In particular, the impact on fishery resources and migratory fish stocks are important.

In terms of Article 194(2) measures should be put in place to minimise, to the fullest possible extent 'pollution from installations and devices used in exploration or exploitation of the natural resources of the seabed and subsoil'. These should, in particular, include measures to regulate the design, construction and operation of such installations or devices. These measures must 'protect and preserve rare or fragile ecosystems as well as the habitat of depleted, threatened or endangered species and other forms of marine life'.

The legal obligation of signatory States in respect of seabed mining has been determined and outlined by the Seabed Disputes Chamber of the International

4 Article 55-Article 75.

5 Part vi of unclos. 
Tribunal for the Law of the Sea. ${ }^{6}$ This determination requires State laws and regulations governing seabed mining to be 'no less effective than international rules, regulations and procedures'. Thus State laws cannot be less effective than the International Seabed Authority Mining Code. The Seabed Disputes Chamber further determines that:

States have a direct obligation under international law to ensure that seabed mining activities are governed in accordance with the precautionary approach, employing best environmental practice and conducting prior environmental impact assessment.

In other words 'an effective state response to these obligations ultimately requires an appropriate national legislative framework' to regulate seabed mining. ${ }^{7}$ Granting seabed mining rights in the absence of such a legislative framework would accordingly be contrary to UNCLOS.

\section{$2.2 \quad$ Other International and Regional Agreements}

There is a wide range of other international agreements that are of relevance to seabed mining in national jurisdictions, if the nation in questions is signatory to these. These include the Convention on the Prevention of Marine Pollution by Dumping of Wastes and Other Matter (London Convention), Convention on the Conservation of Migratory Species of Wild Animals and the Convention on Biological Diversity.

Furthermore, there are a number of regional treaties that govern marine activities between signatory nations. ${ }^{8}$ For example, Angola, Namibia and South Africa are signatories to the Benguela Current Convention (BCC).

6 Seabed Disputes Chamber of the International Tribunal for the Law of the Sea, 'Responsibilities and Obligations of States Sponsoring Persons and Entities With Respect to Activities in the Area - Advisory Opinion', 1 February 2011, list of cases: no. 17 para. 214: UNCLOS Articles 208(3) and 209(2) 01.

7 Benkenstein, A. (2014). Seabed Mining: Lessons from the Namibian Experience. SAIIA.

8 Including Convention for Co-operation in the Protection and Development of the Marine and Coastal Environment of: West and Central African Region (1981); Mediterranean Sea (1976); Wider Caribbean Region, (1983); Eastern African Region (1985); South-east Pacific (1981); North-east Atlantic OSPAR Convention (1992); South Pacific Region (1986); Baltic Sea Area (1992); Framework Convention for the Protection of the Marine Environment of the Caspian Sea; Kuwait Regional Convention for Co-operation on the Protection of the Marine Environment from Pollution (1978); Regional Convention for the Conservation of the Red Sea and the Gulf of Aden Environment (1982). 
The всC provides a good example of the interaction between seabed mining and regional agreements, as Namibia and South Africa have existing proposals for marine phosphate mining and prospecting respectively.

The вСС aims to facilitate cooperation and mutual responsibility of the three signatory nations in respect the Benguela Current Large Marine Ecosystem. The BCC seeks to ensure environmentally responsible industrial development and cooperation between the three nations in order to protect biodiversity, maintain ecological integrity and minimise risk of long-term or irreversible impacts caused by human activities. The Preamble states that a priority of the BCC is to minimise pollution from marine mining. A further priority is to ensure that policies, laws and regulations of the three signatory nations are harmonised so that 'industrial activities in one country [do] not impact the coastal or marine environment of another country' (ibid).

Relevant Articles of the BCC related to seabed mining include Article 4 which outlines 'General Principles' to be followed by signatory nations. These include:

a) The cooperation, collaboration and sovereign equality principle;

b) sustainable use and management of the marine resources;

c) the precautionary principle;

d) prevention, avoidance and mitigation of pollution;

e) the polluter pays principle; and

f) protection of biodiversity in the marine environment and conservation of the marine ecosystem.

In order to give effect to the objective of the всC and the principles above, signatory parties are required to:

1) take all possible steps to prevent, abate and minimise pollution and take the necessary measures to protect the marine ecosystem against any adverse impacts;

2) undertake environmental impact assessments for proposed activities that are likely to cause adverse impacts on marine and coastal environments;

3) apply management measures based on the best scientific evidence available;

4) where possible, reverse and prevent habitat alteration and destruction; and

5) protect vulnerable species and biological diversity.

The вСC requires signatory states to 'agree on, where necessary, measures to prevent, abate and minimise pollution caused by or resulting from exploration and exploitation of the continental shelf and the seabed and its subsoil'. Article 8 further requires the Commission agree on conservation and management measures concerning transboundary marine resources and the environment'. 
The Bсс thus would require a cooperative approach to seabed mining to ensure that 'activities in one country do not impact on the marine environment of another country'. Such regional treaties are particularly important where signatory nations share marine and fishery resources where a seabed mining activity of one nation would negatively impact on the marine environment, fishery resources and ocean economy activities of a neighbouring country. ${ }^{9}$

\section{$3 \quad$ Seabed Mining in National Jurisdictions}

This section aims to provide a comparative analysis of legal and policy approaches adopted by other countries in relation to seabed exploration and exploitation. It offers insights into legal mechanisms and principles that have been used in response to seabed mining. Proposals for seabed mining, for both exploration and exploitation, within the exclusive economic zones of coastal States have been concentrated on six nations or areas, namely New Zealand, Australia, Namibia, South Africa, Mexico and the Pacific Islands (including Fiji, Papua New Guinea, Tonga, Vanuatu, Solomon Islands and Cook Islands). ${ }^{10}$ This section will review each of these in turn.

In brief, there has been considerable resistance to seabed extraction proposals in all of these cases and in most cases governments have opted for a cautious approach to seabed mining in the form of moratoria, permanent bans or refusal of project proposals. Whereas Namibia and the Northern Territory of Australia placed a moratorium on phosphate mining and bulk seabed mining respectively, New Zealand's Environmental Protection Agency refused its first application for consent to undertake marine phosphate mining and Mexico's Secretary of Environment and Natural Resources (SEMARNAT) denied environmental authorisation for its first marine phosphate mine proposal. Several other jurisdictions have also established moratoria on oil and gas exploration and production in their exclusive economic zones. Papua New Guinea has approved an exploitation right for seabed mining. However, actual seabed mining operations have not yet commenced.

\subsection{Namibia: Moratorium on Marine Phosphate Mining}

Namibia's environmental management framework was established by the Environmental Management Act, 2007 (EMA). The EMA sets out a range of

9 Ministerial meetings of the Benguela Current Commission (вСС, 2013).

10 REPRISK (2015). Deep Sea Extractive Activities: Seabed Mining and Deep Sea Drilling. 
environmental principles intended to mitigate and avoid adverse impacts of activities. Regulations developed in terms of EMA list certain activities that may not be undertaken without an environmental clearance certificate.

The Act lists 'resource removal, including natural living resources' as an activity that requires an environmental clearance. The Regulations moreover specifically refer to 'mining and quarrying' activities including 'resource extraction, manipulation and forms of mining or extraction of any natural resources whether regulated by law or not.'

Mining licenses in Namibia are granted under the Minerals (Prospecting and Mining) Act, 1992 with the application process set out in s.91. The Minerals Act provides for attaching environmental conditions in issuing mining licenses and requires

An estimate of the effect which the proposed prospecting operations and mining operations may have on the environment and the proposed steps to be taken in order to minimize or prevent any such effect.

Furthermore, before mining may commence, the environmental commissioner must decide on whether the activity requires an environmental impact assessment.

In 2011 the Ministry of Mines and Energy granted mining licences to two companies, Namibian Marine Phosphate and LL Namibia Phosphates, for the exploitation of phosphate deposits off the coast of Namibia. ${ }^{11}$ The mining licences were granted subject to the approval of an Environmental Impact Assessment. In January 2012 Namibian Marine Phosphate submitted a draft Environmental Impact Assessment and Environmental Management Plan for the proposed Sandpiper Phosphate Mining Project (The Sandpiper Project).

The Sandpiper Project would involve dredging the seabed in Namibia's exclusive economic zone at depths of $3 \mathrm{~m}$ and removing large volumes of sediment, up to 5.5 million tonnes annually. The operations expected an annual production of up to 3 million tonnes of phosphate rocks. Sediment would be stored on the vessels and thereafter transferred to land for processing which involves separation of phosphate from other marine sediment. ${ }^{12}$

11 Benkenstein, A. (2014). Seabed Mining: Lessons from the Namibian Experience. SAIIA.

12 Midgley, J., 2012. Environmental Impact Assessment Report for the Marine Component. Sandpiper Project. Proposed recovery of phosphate enriched sediment from the marine Mining Liscence Area No. 170 off Walvis Bay Namibia - Environmental Scoping Report (Final Report, April 2012). 
As part of the Environmental Impact Assessment, specialist studies were undertaken that included potential impacts on seabirds and marine mammals, fish and fisheries, water column dynamics, macrobenthos and jellyfish. ${ }^{13}$

There was considerable opposition to the Sandpiper Project. A number of civil society organisations (both local and international) ${ }^{14}$ and fishery industry associations ${ }^{15}$ strongly opposed the granting of rights and campaigned for a review of the decision. ${ }^{16}$ Furthermore, independent scientists raised strong objections against the Sandpiper Project and the EIA based on environmental impacts. These included the direct destruction to benthic habitats; release of hydrogen sulphide concentrations; release of heavy metals and bioaccumulation in the food chain in turn impacting on fisheries; reduced phosphorous content in the seabed which results in oxygen depletion and toxicity of processing plants on shore near Walvis Bay. ${ }^{17}$

In response to that opposition and the potential impacts on Namibia's fishing industry, the Minister of Fisheries and Marine Resources took steps to establish a moratorium on marine phosphate mining. This led to a cabinet decision in September 2013 to establish an 18 month moratorium on marine phosphate mining. The decision outlined a number of concerns from the Namibian Government:

Government is concerned that the removal of soft sediment from the seabed along with living organisms and the suspension of fine sediment in the seawater may affect the functioning of the marine ecosystem negatively. The ministry is further concerned that any contamination or suspended particles from mining activities may have adverse effects on the fish larvae and their development and thus [we] need to investigate the breeding and nursing areas, breeding patterns of the commercially

13 Benkenstein, A. (2014). Seabed Mining: Lessons from the Namibian Experience. SAIIA.

14 Including Earth Organisation Namibia, the Deep Sea Mining Campaign and Swartkopmund Matters.

15 Including the Namibian Hake Fishing Industry Association and the Confederation of Namibian Fishing Associations.

16 Komnenic, A. (2013). Namibia imposes moratorium on coastal phosphate mining. Mining. com<http://www.mining.com/namibia-imposes-moratorium-on-coastal-phosphate-min ing-41520/> Accessed April 2016.

17 Currie, B. (2014). Investigation of cumulative impacts on the marine ecosystem from mining of phosphorites off the Namibian coast; Solbakken, et al. (2014). Preparing for an Assessment of Environmental Impacts from Onshore and Offshore Phosphate Mining Activities in Namibia. 
important species in relation to the mining activities, as well as the current dynamics. ${ }^{18}$

A major rationale for the moratorium was lack of knowledge on the potential impacts of marine phosphate mining on the marine environment and fisheries resources. The Minister of Fisheries and Marine Resources announced that 'information collected during the moratorium would provide an indication as to whether marine phosphate mining and the fishing industry can co-exist.' The Minister further stated that:

The Namibian government is committed to ensure that proper scientific investigations are carried out that will allow it to make an informed decision about the future of phosphate mining in Namibia. ${ }^{19}$

Accordingly, the Namibian government subsequently commissioned an independent study and environmental impact assessment of the impacts of marine phosphate mining aligned to broader strategic environmental assessments on the Namibian marine environment. The Fisheries and Aquaculture section of the Norwegian-based Foundation for Scientific and Industrial Research (SINTEF) and the Institute for Marine Research were commissioned to conduct these studies. ${ }^{20}$

In 2017 Namibia's Environmental Commissioner issued an environmental clearance certificate for the Sandpiper Project. This led to a public outcry resulting in the Minister of Environment and Tourism cancelling the environmental clearance certificate. Uncertainty and contestation related to the Sandpiper Project is on-going and the issue is highly politicised.

\subsection{New Zealand: Refusal of Marine Phosphate Mining Application}

On 14 May 2014 Chatham Rock Phosphate Limited (Chatham Rock) applied to the Environment Protection Authority for marine consent ${ }^{21}$ to mine phosphate in Chatham Rise, located $400 \mathrm{~km}$ east of Christchurch. The application

18 Namibian Government Cabinet Moratorium, 2013.

19 Haufiku, M. (2014). Moratorium on phosphate mining remains. New Era https://www .newera.com.na/2014/04/11/moratorium-phosphate-mining-remains/ Accessed May 2016.

20 Draft reports related to the overall plan for the Strategic Environmental Assessments have been completed by sinte F (Solbakken, et al. (2014). Preparing for an Assessment of Environmental Impacts from Onshore and Offshore Phosphate Mining Activities in Namibia).

21 In terms of the Exclusive Economic Zone and Continental Shelf (Environmental Effects) Act 2012 (the EEz Act). 
sought consent to commence operations over a $10192 \mathrm{~km}^{2}$ area for a 35 year period. Chatham Rock Phosphate Limited later withdrew the application for operations in an Eastern mining block on 1 August 2014 reducing the total area to $5207 \mathrm{~km}^{2}$. In its application Chatham Rock sought a mining permit (MPL 55549 ) to mine a total area of $105^{2} \mathrm{~km}^{2}$ over 35 years. ${ }^{22}$ The application sought to mine three $10 \mathrm{~km}^{2}$ each year at depths between $250 \mathrm{~m}$ and $450 \mathrm{~m}$ with an expected annual production of up to 1.5 million tonnes. ${ }^{23}$ In the first five years of operations a mining area restricted to $820 \mathrm{~km}^{2}$ was proposed. Chatham Rock provided a description of the proposed mining operation to be undertaken:

The mining was to be carried out by a specially built or modified vessel using a mining system designed by Royal Boskalis Westminster nv (Boskalis). Phosphorite-bearing material was to be retrieved from the seabed by means of a trailing suction drag-head and mechanically processed on board the vessel. Phosphorite nodules greater than $2 \mathrm{~mm}$ would be separated from other material using sieves and logwashers and stored on the vessel. Waste material would then be released close to the seabed, using a discharge (sinker) pipe with a diffuser. ${ }^{24}$

A Decision-Making Committee (DMC) was appointed by the Environment Protection Authority to decide on the application. The application by Chatham Rock drew widespread public attention, with over 294 submissions and large public hearings held by the DMC in Wellington, Hamilton and the Chatham Islands. ${ }^{25}$ On 10 February 2015 the DMC completed deliberations and refused consent.

New Zealand has a comprehensive legal regime on governing seabed mining, which deserves attention. The legislative framework on determining marine consents for marine mining is provided for in its Exclusive Economic Zone and Continental Shelf (Environmental Effects) Act 2012 (the EEZ Act). A large number of provisions in the EEZ Act were considered in the Chatham Rock Phosphate application. ${ }^{26}$

\footnotetext{
22 Currie, D. (2015). Decision on marine consent application: Chatham Rock Phosphate Limited to mine phosphorite nodules on the Chatham Rise.

23 Ibid.

24 Chatham Rock Phosphate, 2014.

25 Currie, D. (2015). Decision on marine consent application: Chatham Rock Phosphate Limited to mine phosphorite nodules on the Chatham Rise.

26 Environmental Protection Authority, 2015.
} 
Section 10(1) outlines the purpose of the Act, which is 'to promote the sustainable management of the natural resources of the exclusive economic zone and continental shelf.'27

Section 10(2) defines sustainable management as 'managing the use, development and protection of natural resources in a way, or at a rate, that enables people to provide for their economic wellbeing while-

(a) sustaining the potential of natural resources (excluding minerals) to meet the reasonable needs of future generations; and

(b) safeguarding the life-supporting capacity of the environment; and

(c) avoiding, remedying or mitigating any adverse effects of activities on the environment.

Section 10(3) states that to fulfil the purposes of the Act, decision-makers must consider decision-making criteria relevant to a particular application ${ }^{28}$ and apply information principles ${ }^{29}$ set out in the Act.

Section 20 lists activities that may only be undertaken in the Exclusive Economic Zone with marine consent. Activities requiring marine consent in terms of Section 20 include:

the removal of non-living natural material from the seabed or subsoil; the disturbance of the seabed or subsoil in a manner likely to have an adverse effect on the seabed or subsoil; the deposit of anything or organism in, on or under the seabed; and the destruction, damage or disturbance of the seabed or subsoil in a manner that is likely to have an adverse effect on marine species or their habitat.

Section 59(2) sets out the criteria that need to be considered in the determination of an application for a marine consent. Relevant criteria that the EPA must consider include:

(a) any effects on the environment or existing interests of allowing the activity, including-

(i) cumulative effects; and

(ii)effects that may occur in New Zealand or in the waters above or beyond the continental shelf beyond the outer limits of the exclusive economic zone;

27 Section 10(1).

28 In this case s59.

29 s61. 
(b) the effects on the environment or existing interests of other activities undertaken in the area covered by the application or in its vicinity, including-

(ii) effects that may occur in New Zealand or in the waters above or beyond the continental shelf beyond the outer limits of the exclusive economic zone; and

(c) the effects on human health;

(d) the importance of protecting the biological diversity and integrity of marine species, ecosystems, and processes;

(e) the importance of protecting rare and vulnerable ecosystems and the habitats of threatened species;

(f) the economic benefit to New Zealand of allowing the application;

(g) the efficient use and development of natural resources;

(h) the nature and effect of other marine management regimes; and

(i) best practice in relation to an industry or activity; and

(j) the extent to which imposing conditions under section 63 might avoid, remedy, or mitigate the adverse effects of the activity; and

In addition, the EPA must have regard to any advice received from the Māori Advisory Committee ${ }^{30}$ and regard to the value of the investment in the activity of the existing consent holder. ${ }^{31}$ In terms of the Act, the decision-maker must also consider the effects of the proposed activities on existing rights. Existing rights may include:

an interest a person has in any lawfully established existing activity such as rights of access, navigation and fishing; the settlement of historical claims under the Treaty of Waitangi Act 1975; the settlement of a contemporary claim under the Treaty of Waitangi as provided for in an Act, including the Treaty of Waitangi (Fisheries Claim) Settlement Act 1992; and a protected customary right or customary marine title recognised under the Marine and Coastal Area (Takutai Moana) Act $2011^{32}$

Section 61 outlines information principles that a decision-maker must apply to the determination of a marine consent application. Section 61 requires decision-makers to make decisions on the best available information and must consider inadequacy and uncertainty of information in its decision. Section 61 directs that 'when the information available in relation to an application

\footnotetext{
$30 \quad$ S. $59(2)(d)$.

$31 \quad S_{59}(3)$.

32 Definition of existing interest, Section 4 of the EEz Act.
} 
is uncertain or inadequate, decision-makers must favour caution and environmental protection.' The Act further requires decision-makers to use their powers to gain as much information as possible by requesting information from the applicant, obtaining advice or commissioning reviews or reports.

Section 62(2) states:

For the avoidance of doubt, the application may be refused if the decision-makers consider that they do not have adequate information to determine the application.

In reaching its decision the Decision Making Committee considered the following effects on the environment:

a) The significant and permanent adverse effects on the benthic environment.

b) The effects of the return of waste material to the seabed following processing aboard the vessel.

c) Effects on the trophic web (including primary production, microbes and zooplankton), fish and other pelagic fauna, rock lobsters, water quality and seabirds.

d) The effects of mining related noise, including on marine mammals; and the risks to biosecurity and human health.

The Decision Making Committee further considered the following threats to existing interests:

a) Interests arising from Treaty of Waitangi settlements.

b) Commercial fishing; marine eco-tourism; customary fishing; and other vessels traversing the area.

c) Effects of the proposal on other marine management regimes, including the Mid Chatham Rise Benthic Protection Area.

d) Interests of Chatham Islanders and the effects of the proposal on Māori and Moriori cultural interests (Currie, 2015).

In summary, the Decision Making Committee refused the application on four grounds:

1. Environmental impact: The Decision Making Committee firstly found that the impacts of the drag head on benthic fauna would be highly destructive. These effects could not be 'avoided, remedied or mitigated'. The mining would take place in the Mid Chatham Rise Benthic Protection Area, an area protected from trawling and dredging. The mining operations would destroy stony coral communities which were regarded by the Decision Making Committee as rare and vulnerable ecosystems. The 
damage would be irreversible' altering the habitat permanently to soft sediment habitats. Furthermore, waste material and effluent returned to the seabed would have considerable effects on benthic habitats both within the mining blocks and the wider environment. ${ }^{33}$

2. Lack of knowledge: There was a lack of information to enable certainty on the impacts on the environment and existing interests. This was attributed to a lack of scientific knowledge of the receiving environment and of the proposed mining operations, regarded as 'the first seabed mining project ever undertaken at such depths anywhere in the world'. With a lack of available knowledge, the Decision Making Committee was accordingly required to 'favour caution and environmental protection'. ${ }^{34}$

3. Socio-economic impacts: The Decision Making Committee considered economic factors and the likely economic benefit to New Zealand of the proposal'. In this consideration the Decision Making Committee determined the following:

'It was not persuaded that the proposal's economic benefit to New Zealand would be of the significance argued by the applicant, or that reliance could be placed on economic benefits as a potential offsetting factor'.

It found that 'seabed mining would be unlikely to generate more than a modest economic benefit to New Zealand and the quantum and distribution of that benefit remained uncertain. This had to be weighed against the significant and permanent adverse effects on the benthic environment' and on other existing interests, particularly the fishing industry.

4. Mitigating impacts: The Decision Making Committee considered whether specific conditions that could be applied to the mining proposal could 'avoid, remedy or mitigate the adverse effects of the activity.' In this consideration it found that impacts 'could not be mitigated by any set of conditions or adaptive management regime that might reasonably be imposed'.

After weighing up factors prescribed to make a decision the Decision Making Committee found that the 'application could not be approved either in part or in whole'. The application for marine consent was accordingly refused. ${ }^{35}$

33 Currie, D. (2015). Decision on marine consent application: Chatham Rock Phosphate Limited to mine phosphorite nodules on the Chatham Rise.

34 Ibid.

35 Ibid. 


\subsection{Northern Territory Australia: Moratorium on Seabed Mining}

In Northern Territory Australia a number of seabed mining proposals and preliminary exploration rights were granted for manganese exploitation in the shallow waters of Groote Eylandt. Mining companies involved included Northern Manganese Limited, Groote Resources Limited and Groote Eylandt Mining Company. ${ }^{36}$

Northern Manganese Limited sought environmental approval to conduct exploratory activities in 2012. It applied for 7 mineral exploration licenses, covering an approximately of $3856 \mathrm{~km}^{2}$ in the shallow offshore Northern Territory. This was known as the Blue Mud Bay Project. Northern Manganese Limited also holds exploration rights for eight tenements $\left(1723 \mathrm{~km}^{2}\right)$ of shallow marine terrain and two islands near Groote Eylandt. This project is known as the Groote Eylandt Project. ${ }^{37}$

The granting of exploration rights generated widespread public concern. In response, the Northern Territory government placed a moratorium on seabed mining. ${ }^{38}$ The Policy Statement of the Moratorium stated that seabed mining is a new and evolving worldwide industry with a minimum number of generally accepted practice standards. The methods applied in seabed mining operations are rapidly changing and there is limited information available on:

a) actual or potential impacts on environment and other resource industries; and

b) methods for managing impacts

This lack of available information decreases the ability of decision-makers to:

a) accurately assess appropriate methodology for management of industry, its development, and sustainability;

b) develop appropriate conditions and authorisations.

The moratorium covered both granting titles permitting exploration for minerals or mining and on issuing authorisations within the coastal waters of the Northern Territory until a review of actual or potential impacts is undertaken. ${ }^{39}$ The review was intended to form the basis for an assessment of possible future development and sustainability of industry. The review was required to:

a) examine practices adopted internationally and in Australia to identify environmental best practices;

36 EPA Northern Territory (2012). Interim Report: Seabed Mining in the Northern Territory.

37 Ibid.

38 Northern Territory Government. (2012). Moratorium on exploration and mining in coastal waters of the Northern Territory until 2015 .

39 Ibid. 
b) identify likely impacts (direct and associated) of seabed mining on the environment and other resources, including commercial and recreational fishing;

c) examine mitigation strategies to manage impacts of exploration and mining;

d) consider advice from Aboriginal Areas Protection Authority - measures to avoid and protect sacred sites.

The overall aim of the review was to:

a) Identify appropriate standards for the Territory which adequately address needs of the community in respect of industry "best practice", protection of the environment, protection of social and cultural impacts, mitigation strategies and community involvement.

b) permit development of regulations and guidelines for assessment of applications to ensure consistency.

The Environmental Protection Agency of Australia produced an Interim Report (2012) which recommended a highly cautious approach to seabed mining and the extension of the moratorium until better knowledge of impacts is available. The moratorium was initially put in place for a period of three years, from March 2012 to March 2015. However, following the lapse of the moratorium period, the Northern Territory extended the moratorium period for a further three years and placed a complete ban on seabed mining in Groote Eylandt.

\subsection{Mexico: Refusal of Environmental Authorisation of a Marine Phosphate Mine}

In September 2014, Odyssey Marine Explorations (an American company) submitted an environmental impact assessment for its planned 'Don Diego' marine phosphate mine in Baja, California's San Ignacio lagoon, near Ulloa Bay. ${ }^{40}$

The project intended to mine 225,000 acres of seabed in five work sites. It was planned that each site would be exploited for 10 years, resulting in a 50 -year long project. Overall, the project planned to extract 350 million tons of phosphate sand from the seabed. ${ }^{41}$

The project was opposed by many stakeholders including the Interamerican Association for Environmental Defense (AIDA), San Juanico residents, the

40 Exploraciones Oceanicas, S. de R.L de C.V. (2014) 'Environmental Impact Assessment Non-Technical Executive Summary'. Available online: http://www.dondiego.mx/wp-con tent/uploads/2014/o6/DD_EIA-Non-Technical-Summary.pdf. Accessed 25 May 2016.

41 Moguel, S. (2016). Mexico protects loggerhead turtles from the Don Diego mine. AIDA. http://www.aida-americas.org/release/mexico-protects-loggerhead-turtles-don-diego -mine Accessed June 2016. 
Centro Mexicano de Derecho Ambiental (CEM DA), local fishing cooperatives, BCS Noticias, WildCoast and Save the Waves Coalition. Civil society raised several concerns including potential impacts on Gray whales, Blue wales, Humpback wales and Loggerhead turtles as a result of noise, disturbance and radioactive releases from marine phosphate mining. ${ }^{42}$

In 2016, the Secretary of Environment and Natural Resources (SEMARNAT) denied environmental authorisation for the Don Diego marine phosphate mining project. The environmental authority found that measures presented by the company for protecting Loggerhead turtles were based on inconsistent information. Furthermore, the authority found that the economic benefits of the project could not prevail over the protection of the natural resources of Ulloa Bay, particularly in relation to threatened species subject to strict standards of protection. ${ }^{43}$

\subsection{Pacific Islands: Seabed Mining Applications}

A number of Pacific Island Nations, namely; Papua New Guinea, Fiji, Tonga, Vanuatu, Solomon Islands and the Cook Islands have granted permits for deep sea mining exploration. The Solwara 1 Project was the most advanced. In 2009 Nautilus Minerals (a Canadian seabed mining company) was granted a mining right for the Solwara 1 Project, for seabed mining in the Bismarck Sea. ${ }^{44}$ It appears that Papua New Guinea government's rationale for granting these rights relates to the potential revenue that could stem from royalties. ${ }^{45}$

There has been significant opposition to the Solwara 1 Project from local communities and not for profit organisations related to the impacts on marine and coastal ecosystems and communities. Recently, the World Bank (2016) published a report titled 'Precautionary Management of Deep Sea Mining Potential in Pacific Island Countries.'46 The report recommended that Pacific Island countries that are supporting or considering deep sea mining activities should 'proceed with a high degree of caution to avoid irreversible damage to

\footnotetext{
42 Ibid.

43 Ibid.

44 Steiner, R. (2009). Independent Review of the Environmental Impact Statement for the proposed Nautilus Minerals Solwara 1 Seabed Mining Project, Papua New Guinea. Conducted for the Bismarck-Solomon Seas Indigenous Peoples Council, Madang, Papua New Guinea.

45 Rosenbaum, H. (2011). Out of our depth! Mining the Ocean Floor in Papua New Guinea.

46 World Bank (2016). Pacific Possible: Precautionary Management of Deep Sea Mining Potential in Pacific Island Countries.
} 
their ecosystems'. The report further stresses the need for strong governance arrangements to ensure that appropriate social and environmental safeguards are in place.

More recently, Nautilus Minerals has run into financial difficulties, and on 21 February 2019, the company filed for protection from creditors under the Canadian Companies' Creditors Arrangement Act (CCAA).

\subsection{Bristol Bay: Moratorium on Oil and Gas Activities ${ }^{47}$}

Oil and gas leasing was first allowed in Bristol Bay in 1986 when the U.S. federal government set aside 5.6 million acres of the southern region of Bristol Bay for oil and gas leasing. ${ }^{48}$ The decision was opposed widely by fishing industry, indigenous communities (Alaska Native Tribes), environmental organisations, the State of Alaska, conservation organisations, recreational users and local seafood and tourism businesses, organised in a coalition called the Fish Basket Coalition. ${ }^{49}$ The Trustees for Alaska and other conservation groups, indigenous communities and the State of Alaska initiated court proceedings to stop the lease sale. The court case was unsuccessful and oil and gas leases were issued. ${ }^{50}$

Potential impacts to fishery resources and marine habitats, cited in independent impact assessments included 'seismic testing, air pollution from ship traffic and the ever-present risk of oil spills'. In particular, impact studies stated that 'the area's harsh weather, rough seas, ice and strong currents would make cleanup and containment of an oil spill difficult, if not impossible.51

In 2010 the Obama Administration cancelled the lease sale and provided temporary protection to Bristol Bay by withdrawing the area for consideration for oil and gas development until 2017. This was followed by steps to permanently protect Bristol Bay. On 16 December 2014, the Obama Administration announced an indefinite Presidential Moratorium on oil and gas drilling in Bristol Bay using powers conferred under the Outer Continental Shelf Lands Act (1953). ${ }^{52}$

47 A further example of a moratorium on offshore oil and gas is Antarctica. Since 1961, the continent has been administered under the Antarctic Treaty, an international agreement to preserve the continent for peaceful scientific study. In 1991 the Madrid Protocol placed a moratorium on mining in Antarctica for fifty years. [Please give details.] This was ratified by all treaty nations by 1998 . There is a strong international campaign aimed at establishing a moratorium on oil and gas drilling in the Arctic Sea.

48 WWF International (2011). The value of commercial fisheries near Bristol Bay, Alaska.

49 Ibid.

50 Ibid.

51 Ibid.

52 The White House (2014). President Obama Protects Alaska's Bristol Bay From Future Oil and Gas Drilling. Press release. https://www.whitehouse.gov/the-press-office/2014/12/16/ 
The basis for the moratorium was partly socio-economic considerations. Bristol Bay supports a $\$ 2$ billion annual fishing industry, regarded as one of the world's most valuable fisheries and provides up to $40 \%$ of America's wild caught seafood. It supports indigenous fishing communities and subsistence fishers throughout Alaska and Pacific Northwest. It is home to Native American sacred lands. The area provides considerable tourism opportunities and revenue, up to $\$ 100$ million in annual recreational fishing and tourism activities. ${ }^{53}$

\section{$4 \quad$ Marine Phosphate Mining in South Africa}

This section provides an in-depth case study into seabed mining in South Africa. The South African case provides strong insights into the potential risks of seabed mining applications in jurisdictions with limited regulatory and governance capacity.

In 2012 and 2014, South Africa's Department of Mineral Resources granted three prospecting rights for marine phosphate to Green Flash Trading 251 (Pty) Ltd (G FT 251), Green Flash Trading 257 (Pty) Ltd (G FT 257) and Diamond Fields International Ltd (DFI Ltd) respectively.

The rights extend over a considerable portion of South Africa's marine environment, together covering more than $150000 \mathrm{~km}^{2}$ or $10 \%$ of its exclusive economic zone. The GFT 251 and GFT 257 prospecting rights cover an area approximately $63637 \mathrm{~km}^{2}$ and $44389 \mathrm{~km}^{2}$ respectively, located off South Africa's West Coast and Southwest Coast. The DFI Ltd prospecting right extends over $47468 \mathrm{~km}^{2}$ within South Africa's Outeniqua Basin. ${ }^{4}$

These prospecting rights have lapsed, and representatives of GFT 251 and GFT 257 have publicly announced, in November 2016, that marine phosphate mining in South Africa would not be financially feasible based on their assessments. Nevertheless, these areas have been earmarked by South Africa's government for seabed mining, despite the fact that they coincide with several existing fishery footprints, critically endangered ecosystems and a number

president-obama-protects-alaska-s-bristol-bay-future-oil-and-gas-drilling.

53 WWF International (2011). The value of commercial fisheries near Bristol Bay, Alaska.

54 Diamond Fields International. (2013). Environmental Management Plan for the proposed Marine Phosphate Prospecting by Diamond Fields International Ltd in the Outeniqua West Licence Area on the Eastern Agulhas, Offshore Mossel Bay. 
of recently proclaimed offshore marine protected areas. Some of the benthic habitat types that coincide with the proposed seabed mining areas don't exist anywhere else in the world. ${ }^{55}$

The next section details issues that need consideration in regulating and governing seabed mining in South Africa. Regulatory approaches adopted in other countries may shed light into some of the regulatory and governance challenges seabed mining poses to South Africa.

\subsection{Environmental Impacts}

There is relatively limited knowledge of the impacts of seabed mining on marine environments. However, preliminary assessments outline considerable and irreversible impacts on marine ecosystems and fishery resources, signifying the need for longer term investigations. ${ }^{56}$ These studies recommend that potentially considerable impacts coupled with the lack of knowledge available on seabed mining, warrants regulatory caution.

WWF-South Africa commissioned a report on potential impacts of marine sediment mining in the west and south coasts of the Western Cape, South Africa. ${ }^{57}$ The report found that seabed mining in existing prospecting areas would have severe and potentially irreversible impacts on seabed habitats. The destruction and permanent alteration of marine habitats would be inevitable in light of the type of mining proposed. ${ }^{58}$

The report found that seabed mining could cause significant and irreversible impacts to biodiversity, ecosystem functioning and fishery resources. In particular, the prospecting rights for marine phosphate mining directly overlap with critically endangered ecosystems, ecologically and biologically significant areas and areas earmarked for protection in terms of an Operation

55 Green Flash Trading. (2012a). Environmental Management Plan in the ocean off Cape Columbine and Cape Infanta, Western Cape Province. Green Flash Trading 257 (Pty) Ltd; Green Flash Trading. (2012b). Environmental Management Plan in the ocean off Adam Se Baai and the area to the south towards Table Bay, Western Cape Province. Green Flash Trading 251 (Pty) Ltd.

56 See Currie, D. 2015; NT Australia EPA, 2012; Rosenbaum, 2011.

57 Currie, J. (2013). Brief Overview of Potential Ecosystem Impacts of Marine Phosphate Mining in the Western Cape, South Africa.

$5^{8}$ Ibid. 
Phakisa ${ }^{59}$ initiative to establish a network of marine protected areas. ${ }^{60}$ Some of the benthic habitat types that coincide with the prospecting areas don't exist anywhere else in the world.

There is also limited knowledge of the ecological importance of seabed ecosystems. It is known that benthic habitats provide habitat, feeding, spawning and breeding areas for a staggering variety of marine species, many of which are commercially important ${ }^{61}$ However, there are considerable gaps in knowledge on the relationship between the seabed and critical ecosystem services.

\subsection{Socio-Economic Impacts}

As seabed mining would have negative impacts on fish stocks it would also impact on revenue, jobs and livelihoods associated with the fishing industry. It is thus important that the socio-economic contributions of fishing are understood and considered in decision-making on seabed mining.

South Africa's commercial fishing industry employs approximately 27000 people directly and 100000 people indirectly. ${ }^{62}$ In the Western Cape, where the prospecting rights are concentrated, the fishing industry contributes approximately $2 \%$ to Gross Geographic Product. ${ }^{63}$

As mentioned, the marine phosphate prospecting areas directly overlap with fishing footprints of several fisheries including hake longline, tuna pole, west coast rock lobster, small pelagics and chokka squid sector. Together, these five fishing sectors provide up to 23000 jobs. ${ }^{64}$ Notably, the prospecting rights coincide with South Africa's only Marine Stewardship Council accredited fishery, which employs 12 ooo people and generates approximately $\mathrm{R}_{4}$ billion in revenue annually. ${ }^{65}$

59 Operation Phakisa is a South African government initiative that seeks to rapidly unlock the economic potential of South Africa's oceans, through fast tracking development of five growth areas, namely: Marine Transport and Manufacturing; Offshore Oil and Gas; Aquaculture; Marine Protection Services and Ocean Governance; and Coastal Tourism.

6o Operation Phakisa. (2014). Marine Protection Services and Governance Final Lab Report.

61 Sink, K. and Attwood, C. (2008). Guidelines for Offshore Marine Protected Areas in South Africa. SANB I Biodiversity Series 9. South African National Biodiversity Institute, Pretoria.

62 Department of Agriculture, Forestry and Fisheries, (2010). Agriculture, Forestry and Fisheries Integrated Growth and Development Plan (GDP), DAFF Sector GDP.

63 Ibid.

64 Brick, K. and Hasson, R. (2016). Valuing the socio-economic contribution of fisheries and other marine uses in South Africa: A socio-economic assessment in the context of marine phosphate mining.

65 Blaine, S. (2012). Miner's marine phosphate plans could harm MSC-accredited fishery. <http://www.bdlive.co.za/articles/2012/07/20/miner-s-marine-phosphate-plans-could -harm-msc-accredited-fishery> Business Day Live Accessed July 2016; Lallemand, P., 
Furthermore, latest estimates suggest that there are approximately 8078 small-scale fishers in South Africa, with the Western Cape home to approximately 1667 small scale fishers. ${ }^{66}$ Small scale fishers directly rely on heathy marine ecosystems for livelihood, nutrition, food security and income. Small scale fishing plays a critical role in providing employment and access to protein in coastal communities. There are approximately 44 coastal communities dotted along the coastline of the Western Cape. ${ }^{67}$

Seabed mining would likely have detrimental impacts on tourism, particularly coastal and marine tourism. Bulk marine sediment mining requires additional coastal developments that have associated impacts. These include desalination plants, beneficiations facilities and processing plants as well as increased shipping. In relation to the Sandpiper Project, residents of Walvis Bay were highly 'concerned about the potential release of toxic elements in the land-based phosphate processing phase'.68

Thus, decision-making, policy and regulation related to seabed mining would need to consider potential negative impacts on existing users and if impacts cannot be avoided, regulatory mechanisms for compensation would need to be devised. With regards to the latter, there is potential difficulty in assessing appropriate compensation for users from renewable industries where their economic benefit is potentially indefinite?

\subsection{South Africa's Legal and Governance Framework}

South Africa's legal and governance framework was not designed to deal with seabed mining. Without specific regulation relevant to seabed mining, applications would tend to be dealt with through existing terrestrial mineral and environmental management legislation. The Mineral and Petroleum Resources Development Act, 2002 (MPRDA) and National Environmental Management Act, 1998 (NEMA), South Africa's existing legislation, are inadequate to govern seabed mining.

Bergh, M., Hansen, M., Purves, M., (2016). Estimating the economic benefits of MSC certification for the South African hake trawl fishery.

Isaacs, M. and Hara, M. (2015). Backing small-scale fishers: Opportunities and challenges in transforming the fish sector. Published by the Institute for Poverty, Land and Agrarian Studies.

67 Ibid.

68 Benkenstein, A. (2014). Seabed Mining: Lessons from the Namibian Experience. SAIIA. 
The Mineral and Petroleum Resources Development Act, 2002 (MPRDA)

The Mineral and Petroleum Resources Development Act does not deal explicitly with seabed prospecting and mining. Many provisions (particularly related to consultation and environmental impact) in the MPRDA are difficult to apply or translate to seabed mining. For instance, legal requirements to consult with landowners, neighbours, community members and other interested and affected parties act as a check and balance against inappropriate prospecting and mining licensing decisions. The importance of a lively civil society has repeatedly been acknowledged by South Africa's Constitutional Court. This check and balance will not be as strong for marine environments where there are no landowners, neighbours or community members.

Marine prospecting applications are accepted or refused by Regional Managers. However, South Africa's exclusive economic zone has not been divided along regional Department of Mineral Resources' administrative lines and functions. Furthermore, the Department of Mineral Resources has no overarching strategy or policy on seabed prospecting and mining. ${ }^{69}$ There are no specific regulatory instruments or guidelines that provide assistance to decision-makers in respect of seabed mining. Nor is there any national and regional database of seabed prospecting and mining or other resource compiled to facilitate the Department of Mineral Resources' consideration of applications.

The Department of Mineral Resources has limited capacity for compliance monitoring and enforcement (CME) of terrestrial operations. In some cases, environmental CME is entirely absent. Accordingly, South Africa's department responsible for environmental management of mineral resource extraction has limited capacity for, or experience, guidance and knowledge of monitoring and enforcing compliance with environmental management plans or programmes and conditions of environmental authorisations in respect of seabed prospecting and mining.

Similarly, mineral authorities across the globe face significant governance and regulatory challenges with terrestrial prospecting and mining related to, amongst other challenges; environmental and social impact; consultation; access to information; rehabilitation and an inability to close operations. These challenges would, in all probability, be magnified in respect of seabed prospecting and mining.

69 In terms of s.3(3) of the MPRDA 'the Minister must ensure the sustainable development of South Africa's mineral and petroleum resources within a framework of national environmental policy, norms and standards while promoting economic and social development'. 
Notably, seabed mining poses significant challenges related to rehabilitation. For example, in terms of $5.24(2 \mathrm{~N})(\mathrm{f})$ an environmental management programme must as 'far as reasonably practicable' include 'measures to rehabilitate the environment affected to its natural or predetermined state'. Under s.24(P)(1) 'an applicant for an environmental authorisation, relating to prospecting, exploration, mining or production' must provide financial provision for rehabilitation. Based on environmental assessments in other countries, rehabilitation in respect of seabed mining seems unlikely, as the 'resultant ecosystem changes in such mined areas could be considered permanent, as recovery to pre-disturbed sediment structures (and hence similar habitat) would occur on geological time scales'.70

\subsubsection{National Environmental Management Act, 1998 (NEMA)}

Seabed mining would potentially fail to comply with a number of provisions in NEMA and similar environmental management legislative frameworks in other countries. Firstly, there is a lack of knowledge of impacts of seabed mining. In such circumstances, NEMA requires a precautionary approach which takes into account the limits of current knowledge about the consequences of decisions and actions.71 Seabed mining thus potentially conflicts with the precautionary principle.

Secondly, NEMA requires development to avoid, minimise or remedy disturbance of ecosystems and loss of biological diversity. In view of independent impact assessments and strategic environmental assessments undertaken in relation to seabed mining, it seems that seabed mining would fail to comply with principles of avoiding, minimising or remedying impact.

Thirdly, NEMA and environmental management legislative frameworks in other countries are usually underpinned by a sustainable development principle, which requires a balancing of social, economic and environmental factors. In South Africa, NEMA requires that development applications should be considered, assessed and evaluated with due regard to the 'social, economic and environmental impacts of activities, including disadvantages and benefits'. Fulfilment of this principle is threatened by the potential socio-economic and environmental impacts of seabed mining.

70 Currie, B. (2014). Investigation of cumulative impacts on the marine ecosystem from mining of phosphorites off the Namibian coast.; Levin, L.; Le, J.T; and Carson, R. (2016). 'Incorporating ecosystem services into environmental management of deep-seabed mining'. Deep-Sea Research.

71 Section $2(4)$ (vii). 
In sum, there are concerns in South Africa's legal, governance and institutional frameworks in relation to seabed mining. Whilst there are gaps in the MPRDA, NEMA has principles that cannot be upheld if seabed mining were to proceed. This would see a seabed mining industry that is unregulated and not subject to state monitoring or enforcement of its compliance with licences and environmental laws. This in turn could facilitate severe and irreversible damage to marine environments and fisheries resources.

\section{$5 \quad$ Conclusion: Legal Principles and Frameworks for Seabed Mining}

The approach, policy positions or decisions adopted by coastal States in relation to seabed mining within their jurisdictions has generally been cautious, with due regard to the precautionary principle. These decisions and approaches have been underpinned by a number of principles, including: lack of knowledge on impacts of seabed mining alongside lack of knowledge of benthic ecosystems (information principle); considerable environmental and socio-economic risks (precautionary principle and sustainability principle); insufficient regulatory, legal, policy, institutional frameworks to cope with seabed mining (governance principle); potential impacts on communities particularly small-scale, traditional and subsistence fishing (fairness principle).

In Namibia and Northern Territory Australia's case, a time-based moratorium has been established, alongside commitments to undertake long-term research and reviews on issues such as: potential environmental impacts; potential impacts on existing marine users, particularly fishing industry (in the form of socio-economic impact assessments or cost-benefit analysis); reviews of potential management regimes to mitigate or reduce impacts; review of potential conditions, permissions and authorisations to regulate seabed mining; and reviews in view of developing potential legislative, regulatory, policy and institutional frameworks in relation to seabed mining.

The rationale for these moratoria and decisions and the cases above can be distilled into a number of prerequisites that these national jurisdictions have committed to before allowing seabed mining to proceed. These are:

1. The undertaking of a strategic environmental assessment: This was a central criteria and tool in Namibia's decision to establish a moratorium on seabed mining. A Strategic Environmental Assessment allows for a long-term and detailed study on potential and actual environmental 
impacts $^{72}$ and on the socio-economic benefits and drawbacks of developing this industry. An environmental impact assessment (EIA) appears to be an inadequate mechanism to deal with risks posed by seabed mining. An EIA only investigates the environmental implications of a single development, at a project level. It does not consider cumulative impacts and assumes that a broader policy decision has already been made, to allow a specific type of development to occur. An activity such as seabed mining, on the other hand, requires a proactive, higher level policy decision on whether it is appropriate or not to allow seabed mining in a specific context in the first place. Such a decision can be guided by a Strategic Environmental Assessment.

2. Socio-economic assessments and cost-benefits analysis: Decision-making on seabed mining further requires proper analysis of potential socio-economic impacts of seabed mining on existing industries and associated jobs and livelihoods - many of which are renewable, unlike seabed mining. ${ }^{73}$ This requires that costs and benefits are weighed up, so that trade-offs are properly informed. In particular, it requires considerations of impacts on commercial and small-scale fishing and associated jobs and livelihoods. Socio-economic assessments and cost-benefits analysis may be part of a strategic environmental assessment, however, in the case of New Zealand and Australia Northern Territory, socio - economic considerations were assessed separately and guided decisions accordingly.

3. Open deliberation on alternatives to seabed mining in respect of resource requirements: An argument asserted in applications for marine phosphate mining in New Zealand, South Africa, Mexico and Namibia is that phosphate is critical for food security and terrestrial phosphate supplies are dwindling whilst demand is increasing ${ }^{74}$. These justifications require further interrogation in decision-making and policy related to seabed mining. Decision-making should be informed by assessments on on the overall desirability of allowing seabed mining in view of

72 Such an SEA can also provide for the collection and management of adequate baseline information in areas where seabed mining is proposed.

73 See Brick and Hasson (2016) for a valuation of South African fishing industry in the context of marine phosphate mining.

74 Diamond Fields International. (2013). Environmental Management Plan for the proposed Marine Phosphate Prospecting by Diamond Fields International Ltd in the Outeniqua West Licence Area on the Eastern Agulhas, Offshore Mossel Bay; Green Flash Trading. (2012a). Environmental Management Plan in the ocean off Cape Columbine and Cape Infanta, Western Cape Province. Green Flash Trading 257 (Pty) Ltd. 
alternative sustainable supply strategies, based on an understanding of market dynamics, use profiles, options for resource recovery and improved management.

4. The development and implementation of appropriate policies, strategies, laws and regulations in relation to seabed mining: ${ }^{75}$ This entails developing a comprehensive framework to guide decision-making, environmental management and compliance monitoring and enforcement. It requires decision-makers to proactively determine the suitability of seabed mining, before development proposals are invested in and considered. This moreover requires considerable institutional and human resource capacity development. ${ }^{76}$ This was an approach adopted by Northern Territory Australia, which provided for a review to 'identify the appropriate standards' and the 'development of regulations, guidelines, or both, for the assessment of applications to ensure consistency of assessment procedures and appropriate determinations'. Developing a regulatory framework for seabed mining should include proper consideration and alignment of regional commitments in respect of potential impacts of seabed mining on neighbouring coastal countries.

5. Establishment of networks of marine protected areas, no-go-areas and fisheries management areas which prohibit and restrict seabed mining, in order to ensure benthic habitats and marine ecosystems receive adequate protection and fishery resources are secured. In many jurisdictions marine protected areas prohibit or provide restrictions on seabed mining in line with provisions on the purposes of marine protection. For example, South Africa's National Environmental Management: Protected Areas Amendment Act, 2014 (NEMPAAA) explicitly provides for the restriction or prohibition of any activities in a marine protected area that may have adverse effects on the purposes of declaring such a marine protected area in the first place. ${ }^{77}$ Section $48(1)$ explicitly states:

Despite other legislation, no person may conduct commercial prospecting or mining, exploration, production or related activities (in a marine protected area).

75 This should include the promulgation of proper technical standards and industry guidelines to minimise damage of operations.

$7^{6}$ This should include proper regulatory provision for seabed mining in national marine spatial planning processes and ocean economic development strategies.

$77 \quad$ s.22A $(\mathrm{g})$. 
In particular, where the purpose of declaring an MPA relates to the conservation and protection of benthic ecosystems, species and habitats, the argument for restricting mining, prospecting, exploration and production activities is heightened.

6. The establishment of legal provisions to ensure liability for environmental damage is assigned to mining operators through appropriate assessment, strict collection and ring-fenced. This is in line with the 'polluter pays' principle entrenched in international law and environmental management regimes of many countries, whereby 'national authorities should endeavour to promote the internalisation of environmental costs and the use of economic instruments, taking into the account that the polluter should, in principle, bear the cost of pollution'. ${ }^{78}$ This should include the establishment of legal mechanisms for compensation to existing marine users for negative impacts stemming from seabed mining.

7. Establishment of legal mechanisms to facilitate proper consultation and stakeholder engagement. This is particularly necessary in view of the fact that checks and balances in the form of legal obligations to consult with landowners, neighbours, community members and other interested and affected parties, are not as robust in relation to marine environments.

These provide a robust set of guidelines or recommendations, based on comparative approaches and processes adopted by other countries, for policy positions and regulatory frameworks for sovereign coastal states to ensure that seabed mining does not disproportionately impact on marine and coastal ecosystems and marine based industries that depend on functioning ecosystems, and associated jobs and livelihoods.

78 Principle 16, Rio Declaration, 1992. 